\author{
Professional Article \\ UDC 330.341 .1 \\ 330.342 .22 \\ DOI 10.5937/skolbiz1-34989
}

\title{
INDUSTRY 4.0 - EXPLORING THE CONCEPT AND IMPLICATIONS FOR BUSINESS
}

\author{
Žarko Đoric ${ }^{*}$ \\ Faculty of Economics, University of Niš, Republic of Serbia \\ Milijana Roganović \\ Novi Sad School of Business, Republic of Serbia
}

\begin{abstract}
Big and significant changes at some point are called revolutions. The revolution involves changes in culture, economy and socio-political institutions and, accordingly, it directly affects people's lives. In that context, Industry 4.0, Industrial Revolution 4.0 or the Fourth Industrial Revolution aimed at creating smart products, procedures, processes and ultimately entire production. Industry 4.0 also produces significant business implications by delivering greater flexibility and robustness along with the highest quality standards in engineering, planning, manufacturing and operational and logistics processes. This will lead to the emergence of dynamic "realtime", self-organizing values that can be optimized concerning various criteria such as cost, availability, and resource consumption. Having in mind the abovmentioned, the paper's primary goal is to look at the effects and problems of Industry 4.0 from the perspective of the business sphere in a general sense. The findings can be useful to companies (and in our country) that are just beginning when it comes to implementing new technologies that bring a new wave of change. On the whole, given its features and changes, it can be argued that this is the most advanced and sophisticated revolutionary period that completely changes the traditional way of doing business. The results of this research are useful to the creators of industrial and innovation policy because they indicate the state and some of the key directions of change to create conditions for the development of Industry 4.0 digitalization and reindustrialization.
\end{abstract}

Keywords: Industry 4.0, digitalization, innovations, business

JEL classification: LO, L6, L8, O14, O33

\footnotetext{
*zdjoric82@gmail.com
} 
96 | Industry 4.0 - Exploring the concept and implications for business

\title{
INDUSTRIJA 4.0 - ISTRAŽIVANJE KONCEPTA I IMPLIKACIJA ZA POSLOVANJE
}

\begin{abstract}
Sažetak: Velike i značajne promene u određenom trenutku nazivaju se revolucijom. Revolucija uključuje promene u kulturi, ekonomiji i društveno-političkim institucijama $i$, shodno tome, direktno utiče na živote ljudi. U tom kontekstu, Industrija 4.0, Industrijska revolucija 4.0 ili Četvrta industrijska revolucija usmerena je na stvaranje pametnih proizvoda, procedura, procesa $i$, na kraju, celokupne proizvodnje. Industrija 4.0 takođe produkuje i značajne poslovne implikacije, pružajući veću fleksibilnost $i$ robusnost, zajedno sa najvišim standardima kvaliteta $u$ inženjeringu, planiranju, proizvodnji $i$ operativnim $i$ logističkim procesima. To će dovesti do pojave dinamičkih, samoorganizujućih vrednosti $u$ „,realnom vremenu”, koje je moguće optimizovati spram različitih kriterijuma kao što su troškovi, dostupnost i potrošnja resursa. Imajući u vidu gore navedeno, primarni cilj rada jeste sagledavanje efekata i problema Industrije 4.0 iz perspektive poslovne sfere $u$ opštem smislu. Nalazi mogu biti od koristi $i$ kompanijama (i kod nas) koje tek počinju sa implementacijom novih tehnologija, koje sa sobom donosi novi talas promena. U celini uzev, može se tvrditi, s obzirom na njegove karakteristike $i$ promene, da je ovo najnapredniji $i$ najsofisticiraniji revolucionarni period koji potpuno menja tradicionalni način poslovanja. Rezultati ovog istraživanja mogu biti od koristi kreatorima industrijske $i$ inovacione politike, s obzirom da ukazuju na stanje $i$ neke od ključnih pravaca promena u cilju stvaranja uslova za razvoj digitalizacije i reindustrijalizacije pod okriljem Industrije 4.0.
\end{abstract}

Ključne reči: Industrija 4.0, digitalizacija, inovacije, poslovanje

\section{INTRODUCTION}

The arrival of the Fourth Industrial Revolution was announced at the Hanover Industrial Technology Fair in 2011, and it soon became a key topic in the search for answers on how to get the economies of EU member states out of recession and be more competitive in global markets. After that, in 2016, at the World Economic Forum in Davos (Switzerland), special attention was paid to this phenomenon, and its complementarity with world global trends based on the neoliberal ideological platform and the corporate economy was emphasized. The Fourth industrial revolution concerns the development of "Industry 4.0", the production paradigm's change, and the economy's digitalization. The intensity of the scope and the complexity of changes in Industry 4.0 were primarily influenced by the dynamic progress of science and technology. It combines physical, digital and biological changes, and the scale it reaches is difficult to measure. The importance and effects of Industry 4.0 are discussed 
within different scientific fields, suggesting its multidimensional and complex nature. Although defined in various ways, it is most often presented as a production level in modern times where technology is not an exogenous factor. More precisely, it is a global concept of digital and industrial transformation that points to a new industrial age transforming traditional production processes and ways of working.

The primary goal of this paper is to explore the meaning, flow and changes that Industry 4.0 brings with it, which radically change the business sphere and the environment in which companies operate. Structurally, the paper consists of three chapters. In the first part, the theoretical aspects of Industry 4.0 are analysed. In the second part, more emphasis is placed on the importance and key determinants that reveal the deeper nature of Industry 4.0. The last chapter is dedicated to business performance and change and the limitations and challenges that Industry 4.0 poses to the business sphere in the most general sense. The potential for reconfiguration of the business paradigm is considered, as well as the limitations that Industry 4.0 brings with it in this regard. Practical ideas and solutions are given based on relevant recent research on how best to adapt, shape and use the potentials that come with the great transformation embodied in Industry 4.0.

\section{THEORETICAL BACKGROUND}

Technical inventions have always encouraged changes in the mode of production and preceded major social changes. Currently, the Fourth industrial revolution is taking place, which brings the process of digitalization, which is characterized by a fusion of various technological breakthroughs that blur the boundaries between the physical, digital and biological spheres (Bazić, 2017; Vujović, 2019; Kamaruzaman, Hamid, Mutalib \& Rasul, 2019; Karabegović \& Karabegović, 2018; Zhou, Liu \& Zhou, 2015; Adhikari, 2020; Ghobakhloo, 2020; Popović, 2020; Prokopović, Prokopović \& Prokopović, 2020; Liao, Deschamps, Loures, \& Ramos 2017; Schäfer, 2018; MacDougall, 2014; Xu, Xu \& Li, 2018; Ghobakhloo, 2018; Fraunhofer IOSP, 2013; United Nations Development Programme UNDP, 2020; Bahrin, Othman, Azli \& Talib, 2016; Kaltenecker \& Kahle-Piasecki, 2019; World Economic Forum, 2016; World Economic Forum, 2020a,b); Lepore, Micozzi \& Spigarelli, 2021; Schwab, 2017; DELOITTE, 2018).

There is still no single and generally accepted definition of Industry 4.0. Briefly, Industry 4.0 ("Industrial Internet", "Smart Industrial Product", "Integrated Industry") is making industrial production virtualized or making the manufacturing industry fully computerized (Sreedharan \& Unnikrishnan, 2017, p. 930). Hermann, Pentek \& Otto (2016), in their research, agree that there is no 
single and generally accepted definition of Industry 4.0 and, accordingly, they identify four design principles:

1. Interconnection: in order to communicate with each other via the Internet of Things, devices, sensors and machines will use wireless communication technologies;

2. Information transparency: by connecting people and objects, it is possible to expect greater availability of information (if not all), which creates a virtual copy of the physical world. In addition to possession, it is no less important to provide information to the right people or objects.

3. Decentralized decisions: In the circumstances of realization of the previous two principles (connection of objects and people, and transparency of information) decisions can be made in a decentralized way using local relevant information), and as such, only in some instances it will be necessary to delegate them to a higher level.

4. Technical assistance: Due to the complexity of production, technical assistance is of great importance, and it is possible to distinguish two systems of such assistance: a)decision support systems that will support people in decision making by aggregating and visualizing information for people and b)physical assistance where advances in robotic technology will enable new types of physical assistance on the factory floor.

In any field of work and activity (production, transport, energy, health), the essence of this new revolution lies in: (1) the smart functioning of ubiquitous networks; (2) the emergence of smart devices and (3) the emergence of smart applications based on big data technology, cloud computing and the Internet of Things. What essentially distinguishes modern technological changes in relation to previous industrial revolutions are: high speed of development; changes in all industrial areas and branches, and the impact on the overall production, management, and administration system.

Industry 4.0 has its advantages (Rise of productivity, Flexibility or agility, Autonomy and decentralized decisions, Product quality improvement, Save energy and resources, Maintenance, Data exchange, Human-robot interaction) and disadvantages (Important investment, Complexity, Risk of technological unemployment, Not useful for mass production) (for detail see: Cros Font, 2018, p. 12-15). 


\section{KEY DETERMINANTS AND MICRO/MACRO SIGNIFICANCE OF INDUSTRY 4.0}

According to one interpretation, there are six major Industry 4.0 trends:

1. Interoperability: Cyber-physical production systems (work surfaces, assembly and production sites) allow people and smart factories to connect and communicate with each other;

2. Virtualization: a virtual copy of a smart factory is created by linking sensor data to a virtual factory model and a simulation model;

3. Decentralization: the ability of a cyber-physical system to make its own decisions and to produce locally, thanks to technologies such as 3D printing;

4. Real-time capabilities: the ability to collect and analyze data and direct insight into them;

5. Service orientation and

6. Modularity: flexible adaptation of smart factories to the required changes by replacing or expanding individual modules (Smit et al., 2016).

The key drivers of Industry 4.0 are:

- Extreme automation - refers to the strong penetration of robotics and AI in the personnel, business and government segments and

- Extreme connectivity - removes obstacles (in terms of distance and time) that stand in the way of faster and deeper communication between machines and people (Liu, 2017, p.115). 
The fourth industrial revolution concerns the increasingly interconnected and complementary digital and physical production systems and, as such, relates to the some specific enabling (disruptive) technologies (see Figure 1 and Table 1). Innovations using the latest technologies increase productivity, competitiveness, and generally a market advantage over other branch industries.

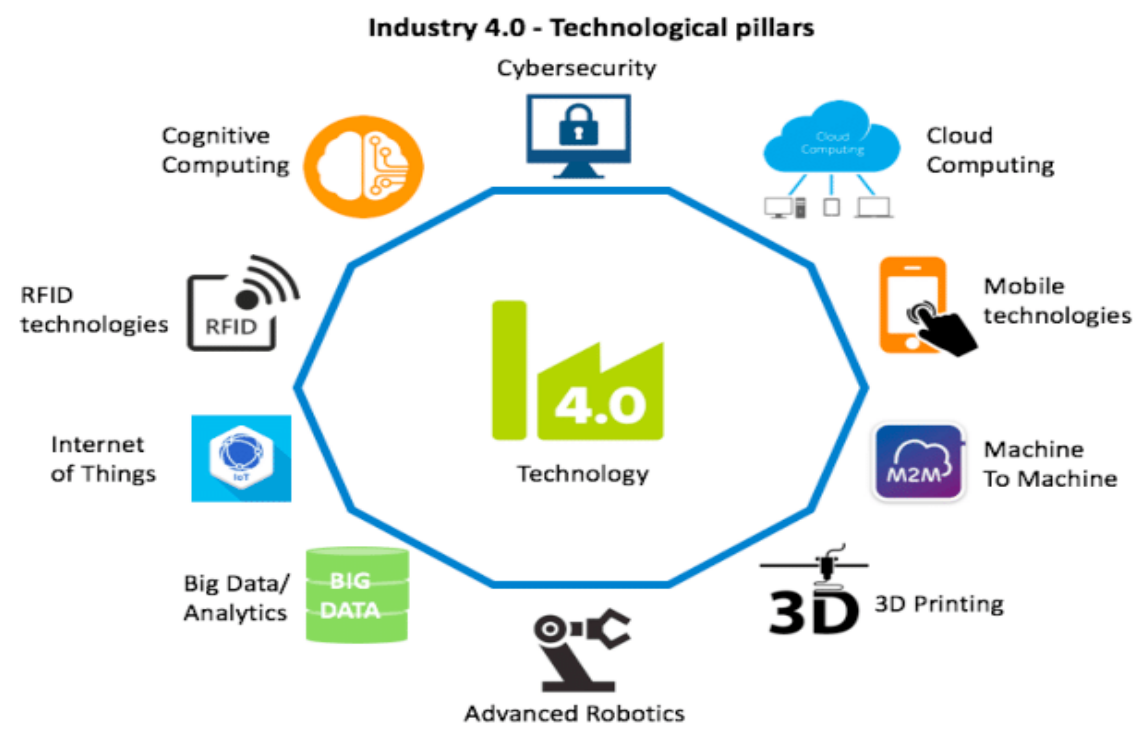

Figure 1. Technologies for industry 4.0

Note. Saturno, M., Pertel, V. M., Deschamps, F., \& Loures, E. D. F. R. (2017). Proposal of an automation solutions architecture for Industry 4.0. In 24th International Conference on Production Research, Poznan, Poland. 
Table 1

Twelve potentially economically disruptive technologies identified by the McKinsey Global Institute

\begin{tabular}{l|l}
\hline Mobile Internet & $\begin{array}{l}\text { Increasingly inexpensive and capable mobile } \\
\text { computing devices and Internet connectivity. }\end{array}$ \\
\hline Automation of knowledge work & $\begin{array}{l}\text { Intelligent software systems that can } \\
\text { perform knowledge work tasks involving } \\
\text { unstructured commands and subtle } \\
\text { judgments. }\end{array}$ \\
\hline The Internet of Things & $\begin{array}{l}\text { Networks of low-cost sensors and actuators } \\
\text { for data collection, monitoring, decision } \\
\text { making, and process optimization. }\end{array}$ \\
\hline Cloud technology & $\begin{array}{l}\text { Use of computer hardware and software } \\
\text { resources delivered over a network or the } \\
\text { Internet, often as a service. }\end{array}$ \\
\hline Advanced robotics & $\begin{array}{l}\text { Increasingly capable robots with enhanced } \\
\text { senses, dexterity, and intelligence used to } \\
\text { automate tasks or augment humans. }\end{array}$ \\
\hline $\begin{array}{l}\text { Autonomous and near-autonomous } \\
\text { vehicles }\end{array}$ & $\begin{array}{l}\text { Vehicles that can navigate and operate with } \\
\text { reduced or no human intervention. }\end{array}$ \\
\hline Next-generation genomics & $\begin{array}{l}\text { Fast, low-cost gene sequencing, advanced } \\
\text { big data analytics, and synthetic biology } \\
\text { ("writing" DNA). }\end{array}$ \\
\hline Energy storage & $\begin{array}{l}\text { Devices or systems that store energy for } \\
\text { later use, including batteries }\end{array}$ \\
\hline 3D printing & $\begin{array}{l}\text { Additive manufacturing techniques to create } \\
\text { objects by printing layers of material based } \\
\text { on digital models. }\end{array}$ \\
\hline Advanced materials & $\begin{array}{l}\text { Materials designed to have superior } \\
\text { characteristics (e.g., strength, weight, } \\
\text { conductivity) or functionality. }\end{array}$ \\
\hline Advanced oil and gas exploration \\
and recovery & $\begin{array}{l}\text { Exploration and recovery techniques that } \\
\text { make extraction of unconventional oil and } \\
\text { gas economical. }\end{array}$ \\
\hline Renewable energy & $\begin{array}{l}\text { Generation of electricity from renewable } \\
\text { sources with reduced harmful climate } \\
\text { impact. }\end{array}$ \\
\hline & $\begin{array}{l}\text { and } \\
\text { and }\end{array}$ \\
\hline
\end{tabular}

Note. McKinsey Global Institute, 2013, p. 4

Viewed from a microeconomic perspective, Industry 4.0 solutions improve operations efficiency, productivity, product quality, inventory management, asset utilization, time to market, agility, workplace safety and environmental 
sustainability. The key activities allowed by the implementation of Industry technologies are shown in Table 2.

Table 2

Industry 4.0 solutions by business function

\begin{tabular}{|c|c|c|}
\hline PLANNING & $\begin{array}{l}\text { Forecasting methods } \\
\text { Collaborative work } \\
\text { Demand management }\end{array}$ & $\begin{array}{l}\text { Integrated enterprise } \\
\text { Safety stock optimization }\end{array}$ \\
\hline DEVELOPMENT & $\begin{array}{l}\text { Product Lifecycle } \\
\text { Management (PLM) } \\
\text { Connected products } \\
\text { Collaborative engineering } \\
\text { Remote monitoring } \\
\end{array}$ & $\begin{array}{l}\text { Remote software update } \\
\text { Collaborative engineering } \\
\text { 3D product models } \\
\text { Process stimulation }\end{array}$ \\
\hline MARKETING \& SALES & $\begin{array}{l}\text { Customer intelligence } \\
\text { Promotions } \\
\text { Digital marketing } \\
\text { e-commerce solutions }\end{array}$ & $\begin{array}{l}\text { Point-of-sale (POS) analytics } \\
\text { User consumer experience } \\
\text { Secure payment systems } \\
\text { Servitization }\end{array}$ \\
\hline INBOUND LOGISTICS & $\begin{array}{l}\text { Track and Trace products } \\
\text { Smart containers } \\
\text { Serialization }\end{array}$ & $\begin{array}{l}\text { Just-in-time (JIT) logistics } \\
\text { Supplier collaboration } \\
\text { Inventory management }\end{array}$ \\
\hline PRODUCTION & $\begin{array}{l}\text { Operational intelligence } \\
\text { Advanced process control } \\
\text { Manufacturing } \\
\text { Execution Systems } \\
\text { Smart tools and machines } \\
\end{array}$ & $\begin{array}{l}\text { Energy management } \\
\text { Predictive maintenance } \\
\text { Quality management } \\
\text { Tracking genealogy } \\
\text { Smart packaging }\end{array}$ \\
\hline OUTBOUND LOGISTICS & $\begin{array}{l}\text { Distribution planning } \\
\text { Inventory management } \\
\text { Warehouse management }\end{array}$ & $\begin{array}{l}\text { Transport management } \\
\text { Track and } \\
\text { Trace products }\end{array}$ \\
\hline $\begin{array}{c}\text { MAINTENANCE } \\
\text { \& SERVICES }\end{array}$ & $\begin{array}{l}\text { Maintenance, Repair and } \\
\text { Overhaul (MRO) } \\
\text { Enterprise Asset } \\
\text { Management (EAM) } \\
\text { Field services }\end{array}$ & $\begin{array}{l}\text { Predictive maintenance } \\
\text { Mobile workforce management } \\
\text { Augmented reality } \\
\text { Condition monitoring } \\
\text { Remote maintenance }\end{array}$ \\
\hline
\end{tabular}

Note. CGI GROUP, 2017, p. 9

In modern business conditions, it is believed that companies have two key imperatives: operating the business and growing the business. Within them, as a necessity, there will be realization of certain business goals reflected in risk reduction, raising the level of productivity, generating additional income, and creating new income sources. As one of the adequate ways to respond to the previously mentioned imperatives and business goals, Industry 4.0 is imposed, which essentially allows transposing rigid, efficiency-focused and manual 
manufacturing to a more dynamic, agile, and automated manufacturing (for detail, see Table 3.).

\section{Table 3}

Key impact of Industry 4.0 at the organizational level

\begin{tabular}{|c|c|c|}
\hline $\begin{array}{l}\text { PRODUCT } \\
\text { IMPACT }\end{array}$ & $\begin{array}{c}\text { KEY } \\
\text { OBJECTIVES }\end{array}$ & TRANSFORMATIONAL PLAYS \\
\hline \multirow[t]{2}{*}{$\begin{array}{c}\text { BUSINESS } \\
\text { OPERATIONS }\end{array}$} & $\begin{array}{l}\text { Productivity } \\
\text { improvements }\end{array}$ & $\begin{array}{l}\text {-Maximizing asset utilization and minimizing } \\
\text { downtime } \\
\text { - Driving direct and indirect labor efficiency } \\
\text {-Managing supply network costs and } \\
\text { synchronization } \\
\text {-Ensuring schedule and plan stability and } \\
\text { accuracy }\end{array}$ \\
\hline & Risk reduction & $\begin{array}{l}\text { - Ensuring raw material price and availability } \\
\text { - Managing warranty and recalls effectively } \\
\text { - Mitigating geographic risks }\end{array}$ \\
\hline \multirow[b]{2}{*}{$\begin{array}{l}\text { BUSINESS } \\
\text { GROWTH }\end{array}$} & $\begin{array}{l}\text { Incremental } \\
\text { revenue }\end{array}$ & $\begin{array}{l}\text { - Finding sources of growth for the core business } \\
\text { - Growing aftermarket revenue streams } \\
\text { - Deepening customer understanding and insights } \\
\text { - Strengthening customer integration and channels }\end{array}$ \\
\hline & New revenue & $\begin{array}{l}\text { - Creating new products and service offerings } \\
\text { - Expanding internationally and in emerging } \\
\text { markets } \\
\text { - Identifying attractive M\&A opportunities }\end{array}$ \\
\hline
\end{tabular}

Note. Deloitte Development LLC. (2016). Deloitte analysis. Graphic: Deloitte University Press | DUPress.com, p. 9.

The main challenges for business when it comes to Industry 4.0 are (CGI Group, 2017, p. 14-15):

1. Awareness: there is still no high level of awareness among companies about the opportunities that Industry 4.0 brings;

2. People: In order to adequately respond to the incorporation of new business models and processes, new business skills and knowledge of employees are needed, as well as a change in the way they perform their daily tasks. By way of illustration, warehouse workers can be replaced entirely by autonomous robots, and the disappearance of physically demanding and routine jobs is expected. New jobs will require a high level of IT competencies, increasing flexibility, and knowledge of analytical and production skills; 
104 | Industry 4.0 - Exploring the concept and implications for business

3. Cybersecurity: In order to amortize cybersecurity risks, industrial IoT devices must be highly secure by design and securely integrated into existing automation and information system architectures;

4. Investments: In order to implement Industry 4.0 solutions, considerable investments are required to create a robust and secure network infrastructure, which in order to be justified, benefits have to be unequivocally and reliably quantified;

5. Collaboration: The delivery of Industry 4.0 solutions will be facilitated by an ecosystem of IT vendors, OT vendors, system integrators and emerging IoT startups. The critical success factor is close collaboration between the business, IT and OT;

6. Standardization: In the coming period, the Industry 4.0 ecosystem will be composed of multiple reference architects, standards and protocols. It is impossible to rely only on existing production standards for Industry 4.0 implementation, but it is necessary to introduce completely new business, architectural and technical standards;

7. IT modernization: Already, hybrid IT environments combining cloud and traditional IT delivery models are on the rise, as cloud computing continues to emerge as a key enabler of both digital transformation and operational efficiency.

\section{INDUSTRY 4.0 AS A CARRIER OF BUSINESS DEVELOPMENT AND A NEW BUSINESS REALITY}

The previous discussion clearly suggests that a change in the way of doing business is in itself inevitable in the age of Industry 4.0, and that there are opportunities that it brings with it. Still, many challenges stand in the way of it.

\subsection{BUSINESS EFFECTS}

The adoption of new technologies brought by Industry 4.0 certainly affects the company's operating parameters such as efficiency, transparency, productivity, flexibility and costs, as well as the creation of new business models and redefining corporate strategies. In the last decade, the digitalization of the industrial sphere has been primarily stimulated by the desire to grow competitiveness and productivity in business. In order to reduce costs, generate higher revenues, increase sales and capitalize on growing market opportunities, companies must invest more in sustained innovation and new technology related to Industry 4.0 ( $\mathrm{PwC}, 2017)$. In order to increase net productivity, it is crucial 
for companies that the technology that Industry 4.0 brings with it be adopted on a larger scale and diffused throughout the ecosystem. However, according to the World Economic Forum (WEF, 2018) research, the adoption of new technologies, with the exception of a few pioneers in this field, is far from fullscale and real exploitation. More than $70 \%$ of industrial companies are still at the start of the journey or remain trapped in the pilot phase, where technology is deployed experimentally at a reduced scale for an extended period due to the inability or a lack of conviction to roll it out at production-system scale (socalled. "pilot purgatory". ${ }^{1}$ ). The way out for companies, and in order to maximize potential gains through raising productivity levels, should be sought in the transition from the pilot phase to adopting technology at scale, across multiple production facilities and through relevant value chains. The next radical changes can be expected in the short and medium-term (WEF, 2018, p. $6)$ :

- Manufacturing will become self-organizing and more autonomous due to a new class of factory workers or a highly connected and smart shop floor;

- Value chains will be seamlessly connected end to end, allowing manufacturers to drive product innovation twice as fast as today;

- Supply chains will connect to a broader supplier ecosystem that will function as a single platform, enabling business-to-business integration;

- Data will drive the creation of new services and innovations in business models.

According to the research ${ }^{2}$ conducted by the World Economic Forum (WEF, 2020b, p.8), the most transformative technologies, with the strongest impact on trade, flows internationally, concern the Internet of Things (IoT) in the supply chain (59\%), Digital payments (56\%), E-commerce platforms (53\%), Cloud computing (52\%) and 5G (49\%). For other technologies the \% are as follows, respectively: Artificial intelligence/Machine learning (45\%), Digital documentation/E-signature/Digital identity (44\%), Smart border systems (38\%), Block chain/Distributed ledger technology (37\%), Robotics and automation (36\%), Digital services other than digital payment (34\%), Open supply chain information systems (34\%), Virtual reality/ Augmented reality/Mixed reality (26\%), 3D printing/Additive manufacturing (19\%) and Others (1\%). According

\footnotetext{
1 "Pilot purgatory" refers to the extended pilot phase and the inability of the production organization (company) to transpose technological solutions from pilots to company-wide rollout.

${ }^{2}$ The research relies on 340 responses from companies from different sectors, of different sizes that operate worldwide. The respondents are from companies with participation in international trade operations.
} 
to research ${ }^{3}$ conducted, also, by the WEF (World Economic Forum, 2018, p.8) the main challenges to scaling up the adoption of technologies (escaping from pilot purgatory in the Fourth Industrial Revolution) in the Industry 4.0 are Lack of resources/knowledge to scale (45\%), High cost of scaling (44\%), Hard to justify business case without short-term impact (44\%) and Pilots demonstrate unclear business value $(41 \%)$. Challenges of minor importance are: Too many use cases to prove out (32\%), numerous platforms to test (27\%), lack of trust in the scalability of platforms (23\%), Vendors not willing to subsidize pilots (22\%), Lack of leadership support and attention (18\%) and Other (4\%). In adopting new technologies, smaller firms highlight difficulties related to dealing with different regulations in different jurisdictions and the lack of digital skills. In comparison, larger firms face increasingly higher capital requirements of technology applied in the trade ecosystem (see: Table 4). Key recommendations for business leaders, all in the function of accelerating the adoption of new Industry 4.0 technologies and thus escaping pilot purgatory, are given in Table 5.

\section{Table 4}

TradeTech adoption challenges by company size, \%

\begin{tabular}{l|c|c|c}
\hline & $\begin{array}{c}\mathbf{1 - 1 9} \\
\text { employees }\end{array}$ & $\begin{array}{c}\mathbf{2 0 - 9 9} \\
\text { employees }\end{array}$ & $\begin{array}{c}\mathbf{1 0 0 +} \\
\text { employees }\end{array}$ \\
\hline Data oligopolies a the & 47 & 38 & 35 \\
\hline $\begin{array}{l}\text { Higher capital requirements, as } \\
\text { complexity of technologies intensifies }\end{array}$ & 49 & 51 & 60 \\
\hline $\begin{array}{l}\text { Fragmented markets with distinct } \\
\text { infrastructure, standards and ecosystems }\end{array}$ & 51 & 49 & 46 \\
\hline $\begin{array}{l}\text { Digital literacy: labor force lacking the right } \\
\text { skill set }\end{array}$ & 68 & 58 & 57 \\
\hline $\begin{array}{l}\text { Dealing with different technology regulations } \\
\text { across jurisdictions }\end{array}$ & 75 & 66 & 57 \\
\hline
\end{tabular}

Note. WEF, 2020b, p.36.

The conducted research relies on 340 responses from companies from different sectors, of different sizes that operate around the world. The respondents are from companies with participation in international trade operations.

\footnotetext{
${ }^{3}$ The research is based on structured interviews with select leaders and experts from the public and private sectors, academia and civil society. Reasons preventing the move from pilot to rollout $\%$ respondents choosing the reason as one of their top three.
} 
Table 5

Industry toolkit for accelerating adoption of technology

\begin{tabular}{|c|c|}
\hline \multirow{3}{*}{$\begin{array}{l}\text { Value delivery } \\
\text { engine }\end{array}$} & $\begin{array}{ll}\text { - } & \text { Connectivity } \\
\text { - } & \text { Augmented reality-guided assembly operations } \\
\text { - } & \text { Real-time IoT-based performance management }\end{array}$ \\
\hline & $\begin{array}{ll}\text { - } & \text { Intelligence } \\
\text { - } & \text { Predictive maintenance } \\
\text { - } & \text { Machine learning-supported, root-cause problem-solving } \\
& \text { for quality claims }\end{array}$ \\
\hline & $\begin{array}{ll}\text { - } & \text { Flexible automation } \\
\text { - } & \text { Robots to automate challenging tasks } \\
\text { - } & \text { Real-time product release }\end{array}$ \\
\hline \multirow{4}{*}{ Scale-up engine } & $\begin{array}{ll}- & \text { Mobilize } \\
\text { - } & \text { Mobilize the organization } \\
\end{array}$ \\
\hline & $\begin{array}{ll}- & \text { Strategize } \\
\text { - } & \text { Set the vision and the value to capture } \\
\end{array}$ \\
\hline & $\begin{array}{ll}\text { - } & \text { Innovate } \\
\text { - } & \text { Spark innovation by demonstrating the value at stake }\end{array}$ \\
\hline & $\begin{array}{ll}\text { - } & \text { Scale-up } \\
\text { - } & \text { Capture full value }\end{array}$ \\
\hline
\end{tabular}

Note. Adapted from World Economic Forum, 2018, p. 9

Although the Industry 4.0 adoption curve - spanning from "the awareness stage" to the "fully-scaled, transformation stage" - is still well-populated and is slowly removing cost barriers and raising the level of technological performance, in essence, the manufacturing sector still exists clear differentiation between three broad groups of companies: first-movers, fence-sitters and loggers. Companies known as "lighthouse" factories are the ones that record enormous gains and are characterized by the adoption of advanced technologies that Industry 4.0 brings with it even in the initial phase. Based on a thorough survey conducted by McKinsey \& Company (2019), which covered over 1,000 production sites worldwide, 16 "lighthouse" companies with the most advanced performance were selected, which use sophisticated Industry 4.0 technologies. $^{4}$ These

\footnotetext{
${ }^{4}$ Lighthouse companies are: 1 . Fast Radius with UPS Additive Manufacturing, US; 2 . Tata Steel Steel Products, NL; 3. Johnson \& Johnson DePuy Synthes Medical Devices, IR; 4. Schneider Electric Electrical Components, FR; 5. Phoenix Contact Industrial Automation, DE; 6. Sandvik Coromant Industrial Tools, SE; 7. Procter \& Gamble Consumer goods, CZ; 8. BMW Group Automotive, DE; 9. Siemens Industrial Automation Products, CN; 10. Bayer Division Pharmaceuticals, IT; 11. Saudi Aramco Gas Treatment, SA; 12. Rold Electrical Components, IT; 13. Danfoss BMW Group Industrial Equipment, CN; 14. Haier Home Appliances, CN; 15. Bosch Automotive, $\mathrm{CN}$ and 16. Foxconn Industrial Internet Electronics, $\mathrm{CN}$
} 
companies, as the most advanced production sites, are a clear proof of how to gain a competitive advantage, strengthen the market position and increase profits so that, instead of waiting for reduced technology and transition costs, they quickly start adapting to new technological solutions and become so-called front-runners, where it benefits from early adoption far outweigh the capital expenditures and transition costs associated with express adoption. In one of the interesting researches for our topic that Deloitte conducted (see: Deloitte Development LLC, 2019) when business leaders were asked to state what are the key challenges within their own strategy of adapting to the changes that Industry 4.0 brings with it, $1 / 3$ stated the absence of a leadership vision. As top challenges to setting an industry 4.0 strategy, choice overload and organizational silos are also highlighted (see: Table 6).

Table 6

Challenges to implementing industry 4.0 strategy for companies

\begin{tabular}{|l|c|c|c|}
\hline & top 1 & top 2 & top 3 \\
\hline Lack of vision on the part of leadership & 12 & 11 & 10 \\
\hline Too many technology choices & 12 & 11 & 12 \\
\hline Organizational or geographical silos & 12 & 13 & 10 \\
\hline Pressure to deliver short-term results & 11 & 9 & 12 \\
\hline Lack of skilled talent & 9 & 10 & 10 \\
\hline Lack of diverse perspectives & 9 & 9 & 9 \\
\hline Resistance to change & 8 & 7 & 7 \\
\hline Lack of strategic imperative & 7 & 9 & 9 \\
\hline Funding challenges & 7 & 8 & 8 \\
\hline The pace of change & 7 & 7 & 7 \\
\hline Fear of failure & 7 & 6 & 6 \\
\hline
\end{tabular}

Note. Adapted from: Deloitte Development LLC, 2019, p. 9

The annual survey was conducted by Deloitte Global, in the period June-August 2018. The survey covered more than 2,000 C-suite executives from all major industrial sectors and covered 19 countries from the European, Asian and American continents. Top challenges in changing strategy for industry 4.0 (Respondents were asked to rank top three challenges, bold 1,2,3\%).

In modern times, companies do business is strongly influenced by online platforms (3D-printing, advanced robotics, Internet of Things and big data), which are increasingly crystallizing as triggers for major changes (International Trade Centre, 2018). These changes have particularly affected the connect pillar (Table 7), undergoing a radical reconfiguration. Therefore the performance of the SMEs sector in the coming period will be determined primarily by their ability to respond to these changes adequately. 
Table 7

Business ecosystem in the SME competitiveness grid

\begin{tabular}{c|l|l}
\hline PILLAR & \multicolumn{1}{|c|}{ THEME } & \multicolumn{1}{|c}{ LEVEL } \\
\hline \multirow{2}{*}{ Compete } & $\begin{array}{l}\text { Quantity and cost requirements } \\
\text { Time requirements } \\
\text { Quality requirements }\end{array}$ & \multirow{3}{*}{ Firm capabilities } \\
\cline { 1 - 2 } Connect & $\begin{array}{l}\text { Connecting to buyers } \\
\text { Connecting to suppliers } \\
\text { Connecting to institutions }\end{array}$ & \multirow{3}{*}{ National environment } \\
\cline { 1 - 2 } Change & $\begin{array}{l}\text { Financing requirements } \\
\text { Skills requirements } \\
\text { Innovation and intellectual property }\end{array}$ & \\
\hline
\end{tabular}

Note. International Trade Centre, 2018, p. 3

Table 8

SME Competitiveness Grid Summary and SME Competitiveness Grid (Business Ecosystem), Serbia country

SME Competitiveness Grid Summary

\begin{tabular}{|c|c|c|c|c|}
\hline \multirow{2}{*}{$\begin{array}{l}\text { Average scores [0-100] } \\
\text { BUSINESS ECOSYSTEM }\end{array}$} & Compete & & Connect & Change \\
\hline & 63.6 & & 2.2 & 68.9 \\
\hline \multicolumn{5}{|c|}{$\begin{array}{c}\text { SME Competitiveness Grid } \\
\text { BUSINESS ECOSYSTEM (Normalized scores) }\end{array}$} \\
\hline Compete & Small & Medium & Large & All \\
\hline Power reliability & 70.2 & 77.7 & 80.1 & 71.8 \\
\hline $\begin{array}{l}\text { Domestic shipping } \\
\text { reliability }\end{array}$ & 71.3 & 85.7 & 77.3 & 71.3 \\
\hline Dealing with regulations & 43.0 & 36.0 & 33.2 & 40.7 \\
\hline $\begin{array}{ll}\text { Customs } & \text { clearance } \\
\text { efficiency } & \\
\end{array}$ & 65.3 & 84.7 & 78.8 & 70.5 \\
\hline \multicolumn{5}{|l|}{ Connect } \\
\hline $\begin{array}{ll}\begin{array}{l}\text { State of } \\
\text { development }\end{array} & \text { cluster } \\
\end{array}$ & & & & 50.2 \\
\hline Extent of marketing & & & & 49.3 \\
\hline Local supplier quality & & & & 55.5 \\
\hline $\begin{array}{l}\text { University-industry } \\
\text { collaboration in R\&D }\end{array}$ & & & & 54.0 \\
\hline \multicolumn{5}{|l|}{ Change } \\
\hline Access to finance & 65.5 & 52.1 & 59.9 & 62.0 \\
\hline $\begin{array}{lll}\begin{array}{l}\text { Access } \\
\text { workforce }\end{array} & \text { to educated } \\
\end{array}$ & 67.0 & 69.6 & 69.1 & 67.6 \\
\hline $\begin{array}{l}\text { Business licensing and } \\
\text { permits }\end{array}$ & 82.7 & 61.7 & 95.3 & 77.2 \\
\hline
\end{tabular}

Note. Adapted from: International Trade Centre, 2019, p. 163.

Scores range from 0 to 100 , a higher score indicates a better outcome. 
This may be important for our country as well, which is still recording half the results in connect pillar (Table 8). In our country, the weakest results are in this segment, with an unsatisfactory situation regarding cluster development (score 50.2/100); low scope of marketing (score 49.3); poor quality of local suppliers (score 55.5), and insufficient intensity of cooperation between universities and industry in the field of research and development (score 54.0).

\subsection{CHALLENGES FOR THE FUTURE}

The essential economic potential of Industry 4.0 is reflected in its capacity to improve adaptive processes, accelerate corporate decision-making, and raise the level of efficiency in production, sales, and marketing. In order to time the Industry 4.0 company transformed into an agile learning organization, skills and potentials are crucial in four key areas (Schuh, Anderl, Dumitrescu, Krüger \& ten Hompel, 2020, p. 23-38):

1. Resources - companies need to ensure that its resources (material, human and technical) be the interface between the digital and physical worlds. There are two important principles here: 1. resources must be able to function in an IT-based way, and it is necessary to choose the right processing techniques and identify data sources. This approach is instead on the targets in a plan (derived from design or assumptions) relies on feedback from the process environment and 2 . data needs to be generated and exchanged in as structured a way as possible to ensure their high quality and reliability, for which the basic assumption is the presence of adequate interfaces between different machines and between people and machines, as well as consensus on the true communication purpose.

2. Information systems - their configuration is crucial to put the available data and information in the function of making adequate decisions. However, for at least two reasons, many companies do not use these systems as support for their decision and that: 1. since they are not delivered in a suitable form, the captured data are not transposed into information, so they cannot be useful as support in their work. In order to avoid the problem mentioned above, the essential rule is that the data must also be delivered in a user-friendly manner, for which it is necessary to meet the appropriate technical requirements for re-access and to incorporate the infrastructure for data processing and uninterrupted delivery of information and 2. starting from the fact that centralized uniform data cannot be useful for different parts of the company, the business imperative is the integration of business systems 
that would ensure the use of common data along the value chain, which improves data use and increases agility. To fulfill the above, it is necessary to introduce an information system architecture for agile companies with a central platform that connects existing IT systems and resources. The preconditions for creating such a platform concern standard interfaces, flexibility, openness, comprehensive IT security and appropriate data quality.

3. Organizational structure - unites the organization from both external and internal perspectives and as such refers to: 1. organic internal organization - it is the antithesis of a mechanistic organization, where a smaller number of limitations and a high level of individual autonomy on accountability for employed staff are envisaged, which is especially important for a dynamic business environment and a workforce with a high level of qualifications. Such an organization brings with it benefits in the sense that it simplifies and accelerates communication between different business sectors and combines different skills of employees by pulling them in the same direction, in the pursuit of the realization of commonly set goals and 2. dynamic collaboration within the value network - thanks to more efficient cooperation within dynamic and flexible networks, companies are able to approach the market more easily and meet its needs more flexibly. Horizontal order data integration and universal data exchange platforms (e.g. for joint development projects) are imposed as one of the catalysts of cooperation. An increasingly important and challenging idea is an increasingly networked, transparent and dynamic market that requires the satisfaction of individualized demand. In order to respond to such a demanding market, it is essential that companies have a clear focus on a limited number of competencies in order to create a differentiated market offering, which is known as the concept of core competence or "strategic success positions". In order to respond more quickly to changing market demands and individual specific needs, it would be beneficial for companies to pool their competencies, where working together, they can design completely new products that they could never create on their own, or this would require a lengthy internal competency building process.

4. Culture - the culture of open communication and a democratic leadership style that evaluates employees according to their key contributions are essential here.

Two reasons dictate the inevitability of transforming the corporate culture, namely: 1. the willingness of employees to constantly review and adjust their own behavior as an adequate response to a vibrant environment, and 2. another 
principle of culture is social collaboration and a high level of trust in social relations among employees that helps accelerate the exchange of knowledge within the company.

As a first principle of the structural area of "culture", readiness for change concerns five key skills that employees must acquire within agile learning companies and that:

1. Recognize the value of mistakes - which when investigated, it is crucial to identify their cause, not so much to look for the main culprit;

2. Openness to innovation - the ability to be friendly to innovation and new methods of action is crucial to initiating radical change, even if it can sometimes be quite unconventional;

3. Data-based learning and decision-making - Modern companies recognize that data-based decision-making produces faster and better results than relying on the experience of individuals. Learning, agile companies are able to do this because they continuously monitor their value-added processes by capturing the relevant data. They then analyze this data, often comparing the digital model to the physical data and base any measures on the results of the analysis. Their employees have confidence in the data and are willing to learn from it and base their decisions on it;

4. Continuous professional development - it is borne in mind that the necessary skills are changing again and again under the influence of continuous changes in production technology and the increasing use of ICT, which imposes the necessity of the concept of lifelong learning for all employees. In the coming period, instead of high demand for specialists with a lot of in-depth knowledge, there will be a growing call for "multi-versatilist" - employees who have an interdisciplinary understanding of interrelated processes and are capable of acquiring the necessary specialist know-how in a short space of time and

5. Shaping change - there is an imperative in which the benefits for those affected by the changes are greater. The company can respond more quickly to external changes and events.

As the second principle of the structural area "culture", social collaboration helps to accelerate knowledge sharing within the organization and is enabled by the combination of three capabilities and that:

- Democratic leadership style - it refers to giving greater freedom of choice to the company's employees, which raises the level of flexibility of the organizational framework and achieves faster decision-making;

- Open communication - in order for a company to be adaptable to market turbulence, its employees should, as a rule, have prompt access to the 
necessary explicit and implicit knowledge. However, contrary to explicit knowledge (available with the help of appropriate information technology), the transfer and exchange of implicit knowledge implies direct and open communication between the people who possess it and the people who seek such knowledge and

- Confidence in processes and information systems - it is borne in mind that such trust enables rapid sharing of documented knowledge, in a role-base, contextual way.

Industry 4.0 produces disruptive changes in existing business models. Business leaders of the future will have to work on creating and implementing completely different business models, and one of the proposals and frameworks is The Capgemini Consulting Industry 4.0 Framework. As the heart of the framework and new industrial paradigms value drivers appear (Capgemini Consulting, 2014, p. 6-20). It is possible to identify eight value drivers along four main pillars in which companies can valorise huge potential through digitization of their own business: 1. Smart Solutions and 2. Smart Innovation (which primarily leverage company growth) and 3. Smart Supply Chains and the 4 . Smart Factory (which mainly drives efficiency).

Smart Solutions refers to: a. Smart products - cyber-physical systems providing new features and functions based on connectivity and b. Smart services - open up paths for entirely new business models and markets through innovative service offerings and delivery models.

Smart Innovation refers to: a. Extended innovation - embraces the creation and distribution of ideas across organizational borders and $b$. Connected Lifecycle Innovation - differs from "ordinary" product lifecycle management in its holistic approach: product-related information is coupled with other relevant data, such as machine parameters or customer order data. It is then analyzed, processed and put to use for generating innovation, enabling data-driven $R \& D$ decisionmaking and business process innovation throughout the entire organization, such as in sales processes.

Smart Supply Chains refers to: a. Agile Collaboration Networks - describes the shift in horizontal integration towards a flexibly defined extended enterprise, enabling manufacturers to focus on core competencies yet allowing them to offer customized products in any market and b. Connected Supply Chains - are formed through the vertical supply network by recreating supply flows on a virtual level, allowing the seamless integration and automation of physical processes and providing companies with dramatically increased transparency.

Finally, Smart Factory refers to: a. Decentralized Production Control transforming the production floor into a marketplace of capacity and production 
needs and b. Data-driven Operational Excellence - exploiting the value of an underestimated resource Data will be the great resource of the next industrial era. Smart Factories will produce huge amounts of it, and combined with the latest analytics technologies and expertise, Data-driven Operational Excellence will help to achieve yet unreachable levels of productivity and product quality.

In order to better adapt its own portfolio to the requirements of Industry 4.0, McKinsey \& Company (2016, p. 14-24) proposes five key recommendations, effective approaches and pragmatic steps that companies should take and adopt:

1. Focus your efforts on a limited number of industry 4.0 applications. This instead of a strategy of simultaneously targeting all possible levers. Mainly as the top five applications through which the full potential of 4IR can be realized along the entire production organization - end to end and top to bottom - highlight the following:

1. Digital performance management - as one of the ways to step into digital production (due to minimal use of resources and offering simplified solutions that can be quickly implemented), this type of application increases the elasticity of management processes and helps to form a way of thinking based on data and digital competencies;

2. Predictive maintenance - it involves mixing various data sets and using complex deep learning algorithms such as neural networks. There are three important prerequisites for the success of this application: a. appropriate change management, b. advanced level of analytical skills and c. huge expertise and knowledge of the respective asset;

3. Yield, energy, and throughput optimization - integrating data from process control systems with other data can certainly be helpful for companies to optimize yield, energy and throughput;

4. Next-level automation - an increased level of automation should be expected in both blue-collar and white-collar work. When it comes to white collars, the greatest potential for optimization is found in functions such as: demand planning (eg, use of predictive analytics) and order management (eg, no-touch order management) in the supply chain process and

5. Digital quality management - by implementing a digital documentation system that provides help record and store quality, relevant production, and service information companies can achieve significant benefits in terms of improved ability to trace errors back, and cost reductions from recalls), as well as high efficiency. Additional value can be activated with the help of semiautomated quality control (e.g., robots, wearables) and advanced quality control, including the use of new sensing technologies (e.g., computer vision). 


\section{Don't be afraid of "workarounds" today, but start laying the IT} foundations for a more robust solution tomorrow

For full Industry 4.0 implementation, the so-called healthy pragmatism is necessary. The real success in the implementation of Industry 4.0 technologies, apart from the progress in the early pilot phase, requires huge investments in the overall technology package, including IoT applications and business logic integration, where the so-called data stack plays a crucial role. In connection with the previous, one of the constructive solutions for articulating the overall data strategy and ensuring the standardization of data in the entire company refers to the formation of a central data management office. This office should perform two key functions: (1) making an effort to establish a professionalized data operating model, in which instead of locking in private data warehouses, data flows are managed in a proactive way, and high-quality data is very accessible and (2) relieve the discussion of the optimal data configuration, with the proposal of a precise map on the way to the target state. Sophisticated solutions to speed up data access are reflected in big data technologies, such as data lakes that can also handle unstructured data (e.g., based on Hadoop) and message-processing technologies (such as ZeroMQ or Apache Kafka). The end result should be a holistic approach to data management throughout the product life cycle, from product planning and engineering to manufacturing and sales.

\section{Build a portfolio of third-party technology providers.}

In the age of Industry 4.0 we are witnessing a shift of focus from the singleprovider model to a set of integrated technology providers, for which the key prerequisites are a well-developed portfolio of potential providers and a strong partner management approach (in terms of the right choice, developing an understanding of the market, and building the capabilities to manage a "best-ofbreed" provider structure).

\section{Build a strong internal team with an agile mindset.}

In order to fully valorize the potential of Industry 4.0, it is crucial for companies to form a dedicated multifunctional team that initiates innovation processes through a culture of openness to constant fast experimentation and iterative improvement, as well as to build strong internal capacities that will support them in that mission. What will contribute to the full implementation of Industry 4.0 in companies is a partnership approach and cooperation between experts from operations (who have the technical domain knowledge), experts from IT (who know about advanced analytics and the company's IT architecture and infrastructure), and experts from a business who know how to link investments to a clear business case).

5. Experiment with new business models.

The technologies behind Industry 4.0, in addition to raising the level of operational efficiency, also lead to the creation of new business models based 
on digital integration and data-based services. It is expected that manufacturers will increasingly be able to draw on real-time data from their installed base to provide new value-added services for their customers.

\section{CONCLUSION}

The fourth industrial revolution represents the transition to a "higher level" of production in which machines will be completely redefined in terms of communication methods and individual functions. The essence of Industry 4.0 is a networked economy, based on the application of information and communication technologies and empowered by the connection of digital devices with production resources, technologies, processes, robots and humans. The complete focus of Industry 4.0 is directed towards one goal comprehensive digitalization and automation of production, logistics and business processes.

The paper presents the way in which digitalization enables the creation of new business models by supporting the industry in shortening time to market while increasing the flexibility and efficiency of companies, thus creating the conditions for cost optimization and more profitable business, and finally, logically, gaining a competitive advantage. Many concepts from the past have undergone significant changes with the advent of the fourth industrial revolution: business models, partnerships, customer relationships, value chains, and even the traditional automation pyramid. Industry 4.0 is not just a simple investment in new technologies and tools that will contribute to improving production efficiency and raising the level of service delivery - it represents a revolution in the entire business and the basis of its growth. In that sense, the paper approaches the elaboration of the impact of Industry 4.0 on key business segments, which can be important for companies operating in our country. The general conclusion is that Industry 4.0 implies changes in standardization, new business models, information security, product availability, research, availability of adequate workforce, work processes and changes in the organizations themselves, which altogether require the more active involvement of companies in adopting and implementing new technologies in order to achieve better business results in the future. Innovations occurring in Industry 4.0 influence market players to reassess competitive positions and to further dedicate themselves to research and development. External factors such as legal regulations, cost pressure, changes in consumer habits, social and cultural aspects, etc. put direct pressure on decision-makers. These pull factors act cohesively with the push factor that predominantly represents 4.0 technologies. The key business changes brought by Industry 4.0 are focused on speed of 
reaction and communication, agility and flexibility, digital automation and the growth of trust. Elements that have been improved consequently affect productivity growth and quality realization of operations (Stajić, 2020, p.63). In the world of tomorrow, business leaders will have to accept a radically different corporate structure under the influence of Industry 4.0 on the transformation of companies. This includes the following (CGI GROUP, 2017, p.5-6):

1. Corporate strategy - Industry 4.0 will impose the existence of a new portfolio of smart products and services while the entry of newly formed companies with their inherent values can be expected. In such circumstances implementing Industry 4.0 will require a C-level commitment;

2. Supply chain management, operations management and product life cycle management - bearing in mind the fact that in case companies and departments operate in silos and without mutual cooperation, it is not realistic to expect a connected demand-driven supply chain to be achieved. The basic premise for linking process control concerns the integration of operations technology (OT) and information technology (IT), operations management and business planning. Finally, digital product models for end-to-end product life cycle management will greatly benefit organizations and

3. Investments - it is necessary to significantly increase investments in digital transformation and reduce the costs of activating old processes and systems.

Finally, we believe that a brief overview of our country regarding Industry 4.0 would be useful. A new industrial revolution in Serbia offers the opportunity to skip some stages of development and masters the latest innovations. Despite the strategic orientation, the current situation in our country is such that there is little interest and that there are very modest results and only slight progress in terms of affirmation of the achievements of Industry 4.0. Despite the indisputable fact that foreign direct investments are a key driver of growth in our country, they mainly (with their amorphous structure) serve as an infusion that contributes to solving problems in the capital balance, but does not significantly contribute to the path of inclusive and sustainable growth. In order to move to a sustainable growth trajectory, it is believed that industrial policies in the tradable products sectors based on Industry 4.0 solutions can play a significant role (Kopaonik Business Forum, 2021). In the coming period, the introduction of intelligent production systems (and products) based on Industry 4.0 solutions is at the same time a way to increase the share of industrial production in the formation of GDP. From the current 20\%, by 2030, Serbia 
could reach the share of industrial production in the formation of GDP in the amount of $35-40 \%$, with the share of Industry 4.0 solutions in industrial output up to $40 \%$ (Kopaonik Business Forum, 2021). Before the digital transformation and renewal of technologies can be implemented using the Industry 4.0 solution, it is necessary to determine the true size of these sectors (capital, assets and number of employees) and establish strategic partnerships with global leaders. Organizational support for the new industrialization strategy could be the Industry 4.0 Competence Center under the auspices of the new Ministry of Digitization and Green Transformation (Kopaonik Business Forum, 2021).

According to the Industrial Policy Strategy 2021-2030 of the Republic of Serbia the key problem areas related to industry 4.0 when it comes to our country are:

1. Technology transfer through foreign direct investment and absorption of new technologies at the enterprise level, which carries the danger that Serbia will dominate the information sector focused on performing technical support and outsourcing of smaller functions, with little progress in implementing their own original solutions that can compete in the global market;

2. In the field of human capital, retaining and attracting talent is recognized as the biggest threat and a low level of on-the-job training and

3. In the domain of demand, there is a noticeable lack of sophistication of demand - most likely due to the weaker purchasing power of consumers.

Given that they make up the majority of the Serbian economy, in the light of Industry 4.0, a key chance for our country is provided in the service sectors with a high content of knowledge and intangible creative products (Industrial Policy Strategy 2021-2030 of the Republic of Serbia). It is also encouraging that in some scientific institutions and IT companies there are experts who are well acquainted with digital technologies (IoT, cloud technology etc.), develop parts of industrial software (PLM and similar) and have practical experience, so they can contribute to the development of Industry 4.0.

According to Majstorović, Đurđanović, Ni, Mitrović and Miletić (2016) the Industry 4.0 model for our country should focus on the following strategic goals: (1) work intensively on strengthening production, especially industrial, with the application of a new concept of education for production at all levels, and especially at the highest - university; (2) focus research on several key products for which research and development for new innovative products should be developed in the medium term (three to five years), including 
scientific and technological research for them; (3) establish an entrepreneurial spirit and develop public-private partnerships, in particular through the active exchange and promotion of information and debate between stakeholders; (4) constantly remove administrative, legal and cultural obstacles to the establishment of competitive, sustainable production in our country, and (5) through government institutions and the chamber system strongly promote and support the interests of Serbian industry at regional and EU level, through all activities.

\section{REFERENCE}

Adhikari, R. (2020). Fourth industrial revolution: From least developed countries to knowledge societies. In S. S. Aneel et al. (Eds.). Corridors of knowledge for peace and development (pp. 41-66). Sustainable Development Policy Institute.

Bahrin, M. A. K., Othman, M. F., Azli, N. N., \& Talib, M. F. (2016). Industry 4.0: A review on industrial automation and robotic. JurnalTeknologi, 78(6-13), 137-143.

Bazić, J. R. (2017). Trendovi promena u društvu i obrazovanju koje generiše Četvrta industrijska revolucija. Sociološki pregled, 51(4), 526-546.

Capgemini Consulting (2014). Industry 4.0 - The Capgemini Consulting View Sharpening the Picture beyond the Hype. www.de.capgemini.com

CGI GROUP. Industry 4.0 - Making your business more competitive. (2017). Available at: www.cgi.com/manufacturing

Cros Font, M. (2018). Technology Mapping for Industry 4.0: a systematic review of Industry 4.0 literature (Master's thesis, Universitat Politècnica de Catalunya).

DELOITTE (2018). The Fourth Industrial Revolution is here-are you ready? Deloitte Insights. 2018 Deloitte Development LLC.

Deloitte Development LLC. (2016). Deloitte analysis. Graphic: Deloitte University Press|DUPress.com.

Deloitte Development LLC. (2019). Deloitte Insights, Success personified in the Fourth Industrial Revolution - Four Leadership Personas for an era of change and uncertainty. 
120 | Industry 4.0 - Exploring the concept and implications for business

Fraunhofer IOSP. (2013). Industry 4.0 - information technology is the key element in the factory of the future. Fraunhofer Institute of Optronics, System Technologies and Image Exploitation, PR, 31.01.2013.

Ghobakhloo, M. (2018). The future of manufacturing industry: a strategic roadmap toward Industry 4.0. Journal of Manufacturing Technology Management, 29(6), 910-936.

Ghobakhloo, M. (2020). Industry 4.0, digitization, and opportunities for sustainability. Journal of Cleaner Production, 252, 1-18.

Hermann, M., Pentek, T., \& Otto, B. (2016). Design Principles for Industrie 4.0 Scenarios. In Proceeding from $49^{\text {th }}$ Hawaii International Conference on System Sciences (pp. 3928-3937).

Kopaonik Business Forum. (2021). Glavne poruke i zaključci KBF 2021. https://www.kopaonikbusinessforum.rs/news/view/glavne-poruke-izakljucci-kbf-2021

International Trade Centre (2018). SME Competitiveness Outlook 2018: Business Ecosystems for the Digital Age. Geneva, Switzerland: The International Trade Centre (ITC).

International Trade Centre (2019). SME Competitiveness Outlook 2019: Big money for small business Financing the Sustainable Development Goals. Geneva, Switzerland: The International Trade Centre (ITC).

Kaltenecker, E., \& Kahle-Piasecki, L. (2019). The Impact of the Fourth Industrial Revolution in the Ownership, Location and Internalization Advantages of Firms: An Exploratory Study. $23^{\text {rd }}$ Cambridge International Manufacturing Symposium University of Cambridge, 26 - 27 September 2019.

Kamaruzaman, F. M., Hamid, R., Mutalib, A., \& Rasul, M. S. (2019). Conceptual framework for the development of 4IR skills for engineering graduates. Global Journal of Engineering Education, 21(1), 54-61.

Karabegović, I., \& Karabegović, E. (2018). Implementacija "Industrije 4.0" primjenom robota i digitalne tehnologije u proizvodnim procesima u Kini. Tehnika-Mašinstvo, 67( 2), 225-231.

Lepore, D., Micozzi, A., \& Spigarelli, F. (2021). Industry 4.0 Accelerating Sustainable Manufacturing in the COVID-19 Era: Assessing the Readiness and Responsiveness of Italian Regions. Sustainability, 2021/13, 2670. 
Liao, Y., Deschamps, F., Loures, E. de F. R., \& Ramos, L. F. P. (2017). Past, present and future of Industry 4.0 - a systematic literature review and research agenda proposal. International Journal of Production Research, 55(12), 3609-3629.

Liu, C. (2017). International Competitiveness and the Fourth Industrial Revolution. Entrepreneurial Business and Economics Review, 5(4), 111133.

Majstorović, V., Đurđanović, D., Ni, J., Mitrović, R., \& Miletić, M. (2016). Novo-Industrijalizacija Srbije i industrijska politika - Pogled 2020/2030. Document from USA-EU-Japan-Serbia Manufacturing Summit. Belgrade, Republic of Serbia.

MacDougall, W. (2014). Industrie 4.0: Smart Manufacturing for the Future. Retrieved from

https://www.gtai.de/GTAI/Navigation/EN/Invest/industrie-4-0.html

McKinsey Global Institute. (2013). Disruptive technologies: Advances that will transform life, business, and the global economy. (2013). Retrieved from https://www.mckinsey.com.

McKinsey\&Company. (2016). Industry 4.0 after the initial hype - Where manufacturers are finding value and how they can best capture it, Retrieved from https://www.mckinsey.com.

McKinsey\&Company. (2019). 'Lighthouse' manufacturers lead the way-can the rest of the world keep up? Retrieved from https://www.mckinsey.com

Ministry of Economy of the Republic of Serbia. Industrial Policy Strategy of the Republic of Serbia 2021-2030. Retrieved from: https://privreda.gov.rs/sites/default/files/documents/2021-08/IndustrialPolicy-Strategy-2021-2030.pdf

Popović, A. (2020). Implications of the Fourth Industrial Revolution on Sustainable Development. Economics of Sustainable Development, 4(2), 45-60.

Prokopović, Ž., Prokopović, K., \& Prokopović, B. (2020). Serbia and the fourth industrial revolution. Journal of Research and Innovation for Sustainable Society (JRISS), 2(1), 11-15.

$\mathrm{PwC}$ (2017). Innovation for the Earth - Harnessing technological breakthroughs for people and the planet. Davos: World Economic Forum. 
Saturno, M., Pertel, V. M., Deschamps, F., \& Loures, E. D. F. R. (2017). Proposal of an automation solutions architecture for Industry 4.0. In Proceeding from $24^{\text {th }}$ International Conference on Production Research. Poznan, Poland.

Schäfer, M. (2018). The fourth industrial revolution: How the EU can lead it. European View, 17(1), 5-12.

Schuh, G., Anderl, R., Dumitrescu, R., Krüger, A., \& Hompel, M. (2020). Industrie 4.0 maturity index. Managing the digital transformation of companies-Update 2020. acatech STUDY.

Schwab, K. (2017). The Fourth Industrial Revolution. New York, NY, USA: Crown Business.

Smit, J., Kreutzer, S., Moeller, C., \& Carlberg, M. (2016). Policy Department A: Economic and Scientific Policy-Industry 4.0. European Parliament, EU, 1-94.

Sreedharan, R., \& Unnikrishnan, A. (2017). Moving Towards Industry 4.0: A systematic review. International Journal of Pure and Applied Mathematics, 117(20), 929-936.

Stajić, N. (2020). Industrija 4.0 u kontekstu upravljanja odnosima u lancu snabdevanja. Ekonomske ideje i praksa, 39, 61-73.

United Nations Development Programme - UNDP. Castañeda-Navarrete, J., Leal-Ayala, D., López-Gómez, C., \& Palladino, M. (2019). Adaptation and adoption of Industry 4.0 in Cambodia.

Vujović, D. (2019). The challenges of income convergence at times of the fourth industrial revolution. Ekonomika preduzeća, 67(1-2), 73-82.

World Economic Forum. (2016). Values and the Fourth Industrial Revolution Connecting the Dots Between Value, Values, Profit and Purpose. Global Agenda Council on Values (2014-2016), White Paper. Geneva Switzerland: World Economic Forum.

World Economic Forum. (2018). The Next Economic Growth Engine Scaling Fourth Industrial Revolution Technologies in Production. White Paper. Geneva Switzerland: World Economic Forum.

World Economic Forum. (2019). Leading through the Fourth Industrial Revolution - Putting People at the Centre. White Paper. Geneva Switzerland: World Economic Forum. 
World Economic Forum. (2020a). Agile Regulation for the Fourth Industrial Revolution - A Toolkit for Regulators. Geneva Switzerland: World Economic Forum.

World Economic Forum (2020b). Mapping TradeTech: Trade in the Fourth Industrial Revolution (2020b). Insight Report. Geneva Switzerland: World Economic Forum.

Xu, L. Da, Xu, E. L. ,\& Li, L. (2018). Industry 4.0: State of the art and future trends. International Journal of Production Research, 56(8), 2941-2962.

Zhou, K., Liu, T., \& Zhou, L. (2015). Industry 4.0: Towards future industrial opportunities and challenges. In Fuzzy Systems and Knowledge Discovery (FSKD) (pp. 2147-2152). IEEE.

Delivered: 01.06.2021.

Accepted: 19.10.2021. 